\title{
Ragam Vegetasi Hutan Rawa Air Tawar di Taman Wisata Alam Jering Menduyung, Bangka Barat
}

\author{
Aziz $^{1}$, Henri ${ }^{*}$, Wahyu Adi ${ }^{2}$ \\ 1Program Studi Biologi, Universitas Bangka Belitung, Bangka 33172; e-mail: biology.henry@gmail.com \\ 2Program Studi Manajemen Sumberdaya Perairan, Universitas Bangka Belitung, Bangka 33172
}

\begin{abstract}
ABSTRAK
Taman Wisata Alam (TWA) Jering Menduyung merupakan salah satu hutan konservasi Bangka Belitung yang terletak di Kabupaten Bangka Barat. Pada kawasan ini mempunyai hutan mangrove primer yang mendominasi seluas 1209,7 Ha dari seluruh tutupan lahan. Selain itu, juga terdapat ekosistem hutan rawa 405,519 Ha dan hutan belukar rawa 478,709 Ha. Hutan rawa air tawar pada beberapa tahun terakhir keadaan vegetasi mengalami banyak gangguan seperti adanya aktivitas pertanian. Penelitian ini dilakukan untuk menganalisis tingkat keanekaragaman vegetasi hutan rawa air tawar di TWA Jering Menduyung. Metode analisis vegetasi menggunakan metode kombinasi antara metode jalur dan metode garis berpetak, sedangkan penempatan jalur menggunakan metode purposive sampling. Hasil penelitian ini menunjukkan bahwa hutan rawa air tawar memiliki 25 jenis tumbuhan yang termasuk kedalam 19 famili. Famili Rubiaceae merupakan jenis yang paling banyak, diantaranya yaitu jenis Ixora paludosa (Blume) Kurz, Psychotria sp., Oxyceros longiflorus (Lam.) T.Yamaz, Psychotria sp.. Melaleuca leucadendron L merupakan spesies yang mendominasi pada tingkat pertumbuhan pancang (115,64\%), tiang $(300 \%)$ dan pohon (300\%). Sementara tingkat semai, spesies yang mendominasi adalah Cyperus sp. (58,62\%). Indeks keanekaragaman Shannon-Weiner yang ditemukan tertinggi berkisar anatara 1,591-2,197 yang ditemukan pada tingkat semai dan pancang. Nilai indeks keanekaragaman Shannon-Weiner pada tingkat tiang dan pohon <1. Distribusi spesies berdasarkan indeks kemerataan Evennes untuk semua tingkat pertumbuhan (semai, pancang, tiang dan pohon) di hutan rawa air tawar menunjukkan distribusi spesies yang tidak sama (0-0,792). Stategi yang tepat dalam pengelolaan hutan rawa air tawar TWA Jerieng Menduyung ini melalui pendekatan partisipatif pada tingkat lanskap untuk perencanaan pengelolaan ekosistem hutan yang efektif dan berkelajutan.
\end{abstract}

Kata kunci: TWA Jering Menduyung, hutan rawa air tawar , keragaman, vegetasi

\begin{abstract}
Jering Menduyung Nature Tourism Park (NTP) is one of the Bangka Belitung conservation forests located in the West Bangka Regency. This area has primary mangrove forests that dominate 1209.7 hectares of all land cover. Besides, there are also 405,519 hectares of the swamp forest ecosystem and 478,709 hectares of swamp forest. Freshwater swamp forest in the last few years the vegetation has experienced many disturbances such as agricultural activities. This study was conducted to analyze the level of vegetation diversity of freshwater swamp forests in Jering Menduyung NTP. The vegetation analysis method uses a combination of the path method and the plotline method, while the placement of the path uses the purposive sampling method. The results of this study indicate that freshwater swamp forests have 25 species of plants that belong to 19 families. The Rubiaceae family is the most abundant species, including the Ixora paludosa (Blume) Kurz, Psychotria sp., Oxyceros longiflorus (Lam.) T.Yamaz, Psychotria sp. Melaleuca leucadendron L is a species that dominates at the level of sapling growth $(115,64 \%)$, poles $(300 \%)$ and trees $(300 \%)$. While the seedling level, the species that dominates is Cyperus sp. (58.62\%). The highest Shannon-Weiner diversity index found ranged between 1.591-2.197 which was found at seedling and sapling levels. Shannon-Weiner diversity index value at the pole and tree-level $<1$. The distribution of species based on the Evenness index for all growth rates (seedlings, saplings, poles, and trees) in freshwater swamp forests shows an unequal distribution of species $(0-0,792)$. The appropriate strategy in the management of Jerieng Menduyung NTP freshwater swamp forest through participatory approaches at the landscape level for effective and sustainable forest ecosystem management planning.
\end{abstract}

Keywords: Jering Menduyung NTP, freshwater swamp forest, diversity, vegetation

Citation: Aziz, Henri, dan Adi, W. (2020). Ragam Vegetasi Hutan Rawa Air Tawar di Taman Wisata Alam Jering Menduyung, Bangka Barat. Jurnal Ilmu Lingkungan, 18(1), 200-208, doi:10.14710/jil.18.1.200-208

\section{Pendahuluan}

Taman Wisata Alam (TWA) Jering Menduyung merupakan salah satu hutan konservasi Bangka Belitung yang terletak di Kabupaten Bangka Barat. 200
TWA Jering Menduyung dikategorikan kawasan yang dihindari terkait rencana penetapan daerah interes untuk pembangunan PLTN, karena masuk dalam kategori kawasan cagar alam, dan lokasinya relatif 
dekat tapak interes (Melawati et al., 2011). Penetapan fungsi pengelolaannya sebagai Taman Wisata Alam (TWA) pada tanggal 27 Juli 2016 berdasarkan Surat Keputusan Kementerian Lingkungan Hidup dan Kehutanan Republik Indonesia nomor 580 tahun 2016. TWA Jering Menduyung mempunyai hutan mangrove primer yang mendominasi hutan tersebut seluas 1209,7 Ha dari seluruh tutupan lahan. Selain itu, kawasan TWA Jering Menduyung juga terdapat ekosistem hutan rawa 405,519 Ha dan belukar rawa 478,709 Ha (BKSDA SUMSEL, 2017).

Hutan rawa air tawar di TWA Jering Menduyung cenderung tergenang ketika musim hujan dan kering saat musim kemarau. Menurut Yusuf \& Purwaningsih (2009), menyatakan kawasan hutan rawa air tawar terdiri atas hutan rawa tergenang permanen, hutan rawa tergenang musiman dan hutan rawa air panas. Menurut Ardhana (2012), hutan rawa secara umum merupakan kawasan dengan tanah yang selalu tergenang air tawar dan daerah landai yang terdapat di belakang hutan mangrove. Hutan rawa memiliki manfaat antara lain sebagai daerah tangkapan hujan, sumber air dan habitat berbagai macam flora dan fauna. Hutan rawa air tawar memiliki peranan penting dalam mengendalikan banjir, mengisi air tanah, membersihkan polusi, habitat satwa dan sebagai tempat rekreasi atau wisata alam (Sharma \& Joshi, 2008).

Ekosistem rawa mempunyai habitat yang unik dengan komunitas tumbuhan yang telah beradaptasi dengan lingkungan setempat (Yusuf \& Purwaningsih, 2009). Pada ekosistem rawa ditemukan pohon berakar lutut yang tunasnya terendam air tetapi bisa bernapas karena adanya rongga. Pohon-pohon ini tajuknya berlapis-lapis, seperti Andina sp., Alstonia sp., Baringtonia sp., Ficus retusa, Dillenia sp., Dyera sp., Pandanus sp. (Ardhana, 2012). Tuheteru \& Mahfudz (2012), menyatakan bahwa spesies pohon yang sering dijumpai dalam ekosistem hutan rawa, yaitu pulai (Alstonia spp.), jelutung (Dyera spp.), simpur (Dillenia spp.), terentang (Campnosperma spp.), jambu-jambu (Sizygium spp.), rengas (Gluta renghas). Pada penelitian Yusuf \& Purwaningsih, (2009), tercatat 38 famili, 80 genus dan 112 spesies pohon yang terdapat di hutan rawa air tawar Rimbo Panti Sumatera Barat.

Kawasan hutan rawa air tawar terdiri atas hutan rawa tergenang permanen, hutan rawa tergenang musiman dan hutan rawa air panas. Beberapa tahun terakhir keadaan vegetasi di kawasan hutan rawa air tawar mengalami banyak gangguan. Data yang ada menunjukkan gangguan utama ekosistem hutan rawa air tawar berupa aktivitas pertanian dan perladangan (Yusuf \& Purwaningsih, 2009). Selain itu, daerah sekitaran TWA Jering Menduyung terdapat kawasan rehabilitasi yang terdiri atas area bekas terbakar, area bekas bukaan sawah, dan lahan kawasan berupa kebun yang telah digarap oleh masyarakat. Vegetasi awal sebelum pembukaan sawah didominasi oleh tegakan gelam (Melaleuca leucadendron L) dengan kondisi rawa. Masyarakat hanya menggunakan area tersebut untuk sawah hanya pada saat musim kemarau atau area saat kering (BKSDA SUMSEL, 2017).

Penelitian dilakukan untuk mengungkapkan data ekosistem hutan rawa air tawar yang umumnya masih sangat terbatas. Kemudian, diharapkan menjadi masukan dalam upaya pengelolaan dan pelestarian kawasan hutan rawa air tawar di TWA Jering Menduyung.

\section{Metode Penelitian}

Penelitian ini dilakukan di hutan rawa air tawar TWA Jerieng Menduyung yang secara geografis terletak pada posisi $105^{\circ} 25^{\prime}-105^{\circ} 33^{\prime}$ BT dan $2^{\circ} 06^{\prime}$ $2^{\circ} 04^{\prime}$ LS. Penelitian ini terdiri dari beberapa tahapan yaitu survei pendahuluan, eksplorasi, analisis vegetasi, pengukuran mikroklimat, pengambilan contoh tanah, dan analisis sifat fisik kimia tanah.

\subsection{Pengumpulan Data Vegetasi}

Pengumpulan data vegetasi hutan rawa air tawar menggunakan kombinasi antara metode jalur dan metode garis berpetak (Indriyanto, 2006). Penempatan metode jalur dengan lebar $20 \mathrm{~m}$ untuk fase pohon, sedangkan fase permudaan (fase semai, pancang dan tiang), serta tumbuhan bawah digunakan metode garis berpetak. Penempatan jalur dilakukan secara sengaja (purposive sampling) pada titik yang dianggap mewakili kawasan hutan rawa air tawar.

Penempatan jalur dilakukan berdasarkan survei pendahuluan sebelumnya. Luas petak ukur untuk masing-masing tingkat pertumbuhan yaitu $2 \mathrm{~m} \times 2 \mathrm{~m}$ (tingkat semai, yaitu sejak perkecambahan sampai tinggi $1,5 \mathrm{~m}$ ), $5 \mathrm{~m} \mathrm{x} 5 \mathrm{~m}$ (tingkat pancang, yaitu tingkat pertumbuhan mencapai tinggi $1,5 \mathrm{~m}$ dengan diameter batang kurang dari $10 \mathrm{~cm}$ ), $10 \mathrm{~m}$ x $10 \mathrm{~m}$ (tingkat tiang atau pohon kecil, yaitu tingkat pertumbuhan pohon muda yang berukuran dengan diameter batang 10-19 $\mathrm{cm}$ ) dan $20 \mathrm{~m} \times 20 \mathrm{~m}$ (tingkat pohon, yaitu tingkat pohon-pohon yang berdiameter batang lebih dari 20 $\mathrm{cm})$.

\subsection{Pengukuran Mikroklimat}

Pengukuran mikroklimat dilakukan pada setiap petak pengamatan. Titik pengukuran terletak pada area pengambilan sampel tanah. Pengukuran dilakukan ketika mengambil sampel tanah dan dilakukan sebanyak 3 (tiga) kali ulangan. Parameter mikroklimat yang diukur meliputi suhu tanah, suhu udara, kelembapan udara, intensitas cahaya. Suhu tanah diukur menggunakan termometer, suhu dan kelembapan udara diukur menggunakan termohigrometer serta intensitas cahaya diukur menggunakan lux meter.

\subsection{Prosedur dan Analisis Sampel Tanah}


Secara umum kajian dan analisis tanah merujuk kepada Foth (1998). Pengambilan sampel tanah terbagi menjadi dua, yaitu sampel tanah utuh dan sampel tanah komposit. Pengambilan sampel tanah utuh diambil menggunakan ring sampel pada kedalaman 0-10 cm. Sampel tanah ini digunakan untuk analisis bobot isi, kadar air dan porositas tanah. Sampel tanah komposit untuk analisis tekstur tanah 3 fraksi, pH tanah, C-organik, kapasitas tukar kation, $\mathrm{P}$ tersedia, $\mathrm{P}$ dan $\mathrm{K}$ potensial. Analisis sifat tanah berupa bobot isi, porositas dan kadar air dilakukan di Laboratorium Biologi, sedangkan analisis sifat kimia tanah 3 fraksi dilakukan di Laboratorium Bioteknelogi Lingkungan, PT Biodiversitas Bioteknologi Indonesia.

\subsection{Analisis Data}

Analisis data digunakan untuk mengetahui kontribusi masing-masing spesies dalam area yang diteliti. Berdasarkan data hasil analisis vegetasi dapat diketahui kekayaan jenis yang ada di kawasan tersebut seperti nilai Kerapatan (K), Kerapatan Relatif (KR), Frekuensi (F), Frekuensi Relatif (FR), Dominansi (D), dan Dominansi Relatif (DR). Selain itu, dihitung nilai Indeks Nilai Penting (INP) untuk mengetahui jenis dan tingkat tumbuhan yang dominan (Gunawan et al., 2011).

Indeks nilai penting dapat dijadikan parameter kuantitatif yang dapat dipakai untuk menyatakan tingkat dominasi spesies-spesies dalam suatu komunitas tumbuhan. Indeks nilai penting dapat dituliskan dengan rumus sebagai berikut (Indriyanto, 2006).

$$
\mathrm{INP}=\mathrm{KR}+\mathrm{FR}+\mathrm{DR}
$$

Kerapatan suatu Spesies (K)

$K=\frac{\text { Jumlah individu }}{\text { Luas seluruh petak contoh }}$

Kerapatan Relatif suatu Spesies (KR)

$K R=\frac{\text { Kerapatan spesies }}{\text { Kerapatan seluruh spesies }} \times 100 \%$

Frekuensi suatu Spesies (F)

$F=\frac{\text { Jumlah petak penemuan suatu spesies }}{\text { Jumlah seluruh petak contoh }}$

Frekuensi Relatif suatu Spesies (FR)

$F R=\frac{\text { Frekuensi suatu spesies }}{\text { Frekuensi seluruh spesies }} \times 100 \%$

Dominansi suatu Spesies (D)

$D=\frac{\text { Luas bidang dasar suatu spesies }}{\text { Luas seluruh petak contoh }}$

Dominansi Relatif suatu Spesies (DR)
$D R=\frac{\text { Dominansi suatu spesies }}{\text { Dominansi seluruh spesies }} \times 100 \%$

\subsubsection{Indeks Keanekaragaman}

Keanekaragaman spesies dapat digunakan untuk mengukur stabilitas komunitas, yaitu kemampuan suatu komunitas untuk menjaga dirinya tetap stabil meskipun ada gangguan terhadap komponenkomponennya. Menurut Ardhana (2012), adapun perhitungan keanekaragaman spesies diperoleh dari rumus Indeks Shannon-Weiner sebagai berikut.

$$
\begin{array}{ll}
\mathrm{H}^{\prime} & =-\sum \mathrm{Pi} \text { In Pi } \\
\mathrm{Pi} & =n \mathrm{i} / \mathrm{N}
\end{array}
$$

Keterangan :

$\mathrm{H}^{\prime}=$ Indeks keanekaragaman Shannon-Wiener

ni $\quad=$ Jumlah individu famili ke $\mathrm{i}$

$\mathrm{N} \quad=$ Jumlah total individu famili yang didapat

$\mathrm{H}<1 \quad=$ Rendah

$1<\mathrm{H}>3=$ Sedang

$\mathrm{H}>3 \quad=$ Tinggi

\subsubsection{Indeks Kemerataan}

Kemerataan akan menjadi maksimum dan homogen jika semua spesies mempunyai jumlah individu yang sama pada setiap lokasi pengamatan. Semakin merata suatu jenis dalam suatu ekosistem, maka semakin tinggi nilai kemerataannya (Setiadi, 2005).

Keterangan :

$$
E=\frac{H}{\operatorname{Ln} S}
$$

$\mathrm{E} \quad=$ Indeks kemerataan

$\mathrm{H}^{\prime} \quad=$ Indeks keanekaragaman spesies

$\mathrm{S} \quad=$ Jumlah spesies

\section{Hasil dan Pembahasan}

\subsection{Jenis Vegetasi Hutan Rawa Air Tawar}

Berdasarkan eksplorasi yang dilakukan pada hutan rawa air tawar di TWA Jering Menduyung tercatat 25 jenis tumbuhan yang termasuk kedalam 19 famili (Tabel 1). Rubiaceae merupakan famili dengan jenis paling banyak, diantaranya yaitu jenis $I$. paludosa (Blume) Kurz, Psychotria sp. dan $O$. longiflorus (Lam.) T. Yamaz. Famili Rubiaceae mendominasi jumlah jenis yang ada, yakni terdiri dari dua jenis vegetasi, sedangkan untuk famili Euphorbiaceae, Casuarinaceae, Malvaceae, Lauraceae, Myrtaceae, Ulmaceae, dan Moraceae hanya terdapat satu jenis saja. Hal ini dikarenakan famili Rubiaceae merupakan famili dengan jumlah individu tertinggi keempat di antara semua angiospermae yang terdiri dari 13.100 spesies yang didistribusikan di 611 genus (Govaerts et al., 2007).

Famili Rubiaceae memiliki kemampuan tumbuh yang baik serta kisaran habitat yang luas. Jenis dari Rubiaceae dilaporkan dapat tumbuh baik pada ekosistem lahan basah seperti hutan sepanjang aliran sungai maupun pada lahan kering seperti savana dan 
padang rumput. Lafare et al. (2018), menyatakan bahwa famili Rubiaceae memiliki distribusi kosmopolitan dan keragaman terbesar secara jelas terkonsentrasi di daerah tropis dan subtropis yang lembab. Famili Rubiaceae memiliki sifat hidrolik sehingga toleransi terhadap perubahan kelembaban tanah (Sedio et al., 2012). Selain itu, famili Rubiaceae dapat memberikan pengaruh kuat pada struktur vegetasi hutan. Sehingga, famili ini sebagai salah satu yang paling cocok untuk digunakan dalam analisis ekologis pengelolaan hutan pada vegetasi tropis karena keterwakilannya dan representasi kebiasaan pertumbuhannya dalam semua jenis (Delprete \& Jardim, 2012).

Myrtaceae dan Pteridaceae famili yang jenisnya ditemukan lebih banyak setelah Rubiaceae. Jenis dari famili Myrtaceae di hutan rawa air tawar antara lain M. leucadendron L dan S. buxifolium Hook. \& Arn. (Tabel 1). Penelitian Lisdayanti et al., (2016), melaporkan bahwa famili Myrtaceae di hutan rawa air tawar Rimbo Tujuh Danau merupakan salah satu famili yang memiliki anggota spesies lebih banyak dibandingkan famili lainnya.

Selain itu, Setiadi (2005), menyatakan bahwa Myrtaceae termasuk famili yang memiliki jenis lebih banyak dari Sapotaceae, Myrtaceae merupakan famili yang mendominasi TWA Ruteng. Purwaningsih, (2009), pada penelitian analisis vegetasi hutan riparian dataran rendah tepi sungai menyatakan bahwa Myrtaceae tercatat sebagai famili dengan jumlah jenis terbesar, selain Dipterocarpaceae. Kemudian Noor (2004), menyatakan bahwa gelam (M. leucadendron L) bisa tumbuh pesat pada lahan terlantar yang masam dan tergenang.

Selain itu, Pteridaceae memiliki anggota spesies antara lain, Pteris sp. dan A. aureum L. (Tabel 1). Pteridaceae yang ditemukan di hutan rawa menunjukkan, bahwa famili ini mempunyai kemampuan beradaptasi yang baik dilingkungan lahan basah. Kelompok famili Pteridaceae mempunyai daya adaptasi yang sangat baik dan bersifat kosmopolitan, dimana dapat ditemukan pada habitat darat maupun air (Abotsi et al., 2015)

Jenis paku-pakuan Pteridaceae yang ditemukan dilokasi penelitian cenderung hidup secara terestrial yaitu Pteris sp. dan A. aureum L. Hal ini dapat diketahui, paku-pakuan Pteridaceae secara umum merupakan tumbuhan paku yang hidup secara epifit, terestrial, dan epilitik (tumbuh pada bebatuan). Selain itu, Pteridaceae lebih sering dijumpai di lingkungan tropis yang lembab (Abotsi et al., 2015).

Tabel 1. Jenis Tumbuhan Hutan Rawa Air Tawar di TWA Jering Menduyung

\begin{tabular}{|c|c|c|c|}
\hline No. & Nama Daerah & Spesies & Famili \\
\hline 1. & Merpala & Ilex cymosa Blume & Aquifoliaceae \\
\hline 2. & Nipah & Nypa fruticans Wurmb & Arecaceae \\
\hline 3. & Iding-iding & Stenochlaena palustris (Burm.f.) Bedd. & Blechnaceae \\
\hline 4. & Rumput & Cyperus sp. & Cyperaceae \\
\hline 5. & Simpur & Dillenia suffruticosa (Griff.) Martelli & Dilleniaceae \\
\hline 6. & Wee Marau & Flagellaria indica $\mathrm{L}$. & Flagellariaceae \\
\hline 7. & Resam & Dicranopteris linearis (Burm. f.) Underw. & Gleicheniaceae \\
\hline 8. & Leben & Vitex pinnata $\mathrm{L}$. & Lamiaceae \\
\hline 9. & Segeger Ayam & Lycopodiella cernua (L.) Pic.Serm. & Lycopodiaceae \\
\hline 10. & Keramunting & Melastoma malabathricum L. & Melastomataceae \\
\hline 11. & Mejangkit & Ficus sp. & Moraceae \\
\hline 12. & Gelam & Melaleuca leucadendron $\mathrm{L}$ & Myrtaceae \\
\hline 13. & Nasi-nasi & Syzygium buxifolium Hook. \& Arn. & Myrtaceae \\
\hline 14. & Kantung Semar & Nephentes mirabilis (Lour.) Druce & Nepenthaceae \\
\hline 15. & Anggrek & Dendrobium sp. & Orchidaceae \\
\hline 16. & Rempenai & Ardisia purpurea Reinw. Ex Blume & Primulaceae \\
\hline 17. & Paku-pakuan 1 & Pteris sp. & Pteridaceae \\
\hline 18. & Paku piyai & Acrostichum aureum L. & Pteridaceae \\
\hline 19. & Akar Hijau & Anonim & Rubiaceae \\
\hline 20. & Akar Tanam & Psychotria sp. & Rubiaceae \\
\hline 21. & Kekait & Oxyceros longiflorus (Lam.) T.Yamaz & Rubiaceae \\
\hline 22. & Memaren & Psychotria sp. & Rubiaceae \\
\hline 23. & Nunok Burung & Ixora paludosa (Blume) Kurz & Rubiaceae \\
\hline 24. & Jerampeng & Melicope lunu-ankenda (Gaertn.) T.G.Hartley & Rutaceae \\
\hline 25. & Mesenong & Leea indica (Burm.f.) Merr. & Vitaceae \\
\hline
\end{tabular}

Hasil jenis vegetasi hutan rawa air tawar di TWA Jering Menduyung tersebut tentu perlu dilakukan upaya pengelolaan dan pelestarian hutan secara berkelanjutan untuk mempertahankan fungsi ekologisnya pada ekosistem tersebut. Pada saat yang sama, pengelola hutan harus mengatasi dampak dari kegiatan pemanenan ini terhadap keberlanjutan pasokan berbagai jasa ekosistem (misalnya, perlindungan terhadap kebakaran, ketersedian air dan hara, dan pelestarian keanekaragaman hayati). Mengatasi tantangan ini tentu membutuhkan pendekatan tingkat lanskap bersama untuk perencanaan pengelolaan hutan (Martins \& Borges, 2007). Oleh karena itu, besarnya dan jenis perlakuan hutan dapat memiliki efek yang berbeda pada keanekaragaman hayati serta struktur hutan (Schall \& Ammer, 2013). Sehingga stategi yang tepat dalam pengelolaan melalui pendekatan partisipatif, 
dikarenakan pendekatan ini sebagai alat penting untuk mengatasi berbagai kepentingan aktor dalam jasa ekosistem dan dengan demikian membantu mengembangkan strategi pengelolaan hutan yang efektif dan berkelajutan (Borges et al., 2017).

\subsection{Kelimpahan Individu dan Nilai Penting Spesies}

Keseluruhan jumlah spesies tumbuhan pada semua tingkat pertumbuhan (semai, pancang, tiang, pohon) terdapat sebanyak 21 spesies dan 17 famili. Jumlah individu pada tingkat pancang memiliki kelimpahan tertinggi (308 individu) sedangkan tingkat pohon memiliki jumlah individu yang paling sedikit (71 individu). Kemudian, jumlah individu pada tingkat semai sebanyak 224 individu dan pada tingkat tiang sebanyak 78 individu seperti pada Tabel 2.

Tabel 2. Daftar Jenis Tumbuhan dan Analisis secara Kuantitatif di TWA Jering Menduyung

\begin{tabular}{|c|c|c|c|c|c|c|c|}
\hline No. & Nama Ilmiah & Nama Lokal & JI & $\mathbf{K R}$ & FR & DR & INP \\
\hline & Semai & & & & & & \\
\hline 1. & Cyperus sp. & Rumput & 93 & 40,435 & 18,182 & & 58,617 \\
\hline 2. & Melaleuca leucadendron $\mathrm{L}$ & Gelam & 40 & 17,391 & 23,636 & & 41,028 \\
\hline 3. & Syzygium buxifolium Hook. \& Arn. & Nasi-nasi & 15 & 6,522 & 16,364 & & 22,885 \\
\hline 4. & Dicranopteris linearis (Burm. f.) Underw. & Resam & 30 & 13,043 & 1,818 & & 14,862 \\
\hline 5. & Melastoma malabathricum L. & Keramunting & 11 & 4,783 & 9,091 & & 13,874 \\
\hline 6. & Pteris sp. & Paku-pakuan & 12 & 5,217 & 5,455 & & 10,672 \\
\hline 7. & Anonim & Akar Hijau & 6 & 2,609 & 5,455 & & 8,063 \\
\hline 8. & Acrostichum aureum L. & Paku Piyai & 8 & 3,478 & 3,636 & & 7,115 \\
\hline 9. & Dillenia suffruticosa (Griff.) Martelli & Simpur & 3 & 1,304 & 3,636 & & 4,941 \\
\hline 10. & Stenochlaena palustris (Burm.f.) Bedd. & Iding-iding & 4 & 1,739 & 1,818 & & 3,557 \\
\hline 11. & Ardisia purpurea Reinw. Ex Blume & Rempenai & 2 & 0,870 & 1,818 & & 2,688 \\
\hline 12. & Ficus sp. & Mejangkit & 2 & 0,870 & 1,818 & & 2,688 \\
\hline 13. & Dendrobium sp. & Anggrek & 1 & 0,435 & 1,818 & & 2,253 \\
\hline 14. & Leea indica (Burm.f.) Merr. & Mesenong & 1 & 0,435 & 1,818 & & 2,253 \\
\hline 15. & Nephentes mirabilis (Lour.) Druce & Kantung Semar & 1 & 0,435 & 1,818 & & 2,253 \\
\hline 16. & $\begin{array}{l}\text { Psychotria sp. } \\
\text { Pancang }\end{array}$ & Memaren & 1 & 0,435 & 1,818 & & 2,253 \\
\hline 17. & Melaleuca leucadendron $\mathrm{L}$ & Gelam & 251 & 81,494 & 34,146 & & 115,640 \\
\hline 18. & Nypa fruticans Wurmb & Nipah & 18 & 5,844 & 9,756 & & 15,600 \\
\hline 19. & Melastoma malabathricum L. & Keramunting & 6 & 1,948 & 12,195 & & 14,143 \\
\hline 20. & Syzygium buxifolium Hook. \& Arn. & Nasi-nasi & 8 & 2,597 & 9,756 & & 12,354 \\
\hline 21. & Vitex pinnata $\mathrm{L}$. & Leben & 6 & 1,948 & 9,756 & & 11,704 \\
\hline 22. & Dillenia suffruticosa (Griff.) Martelli & Simpur & 4 & 1,299 & 7,317 & & 8,616 \\
\hline 23. & Ardisia purpurea Reinw. Ex Blume & Rempenai & 4 & 1,299 & 4,878 & & 6,177 \\
\hline 24. & Melicope lunu-ankenda (Gaertn.) T.G.Hartley & Jerampeng & 3 & 0,974 & 4,878 & & 5,852 \\
\hline 25. & Oxyceros longiflorus (Lam.) T.Yamaz & Kekait & 3 & 0,974 & 2,439 & & 3,413 \\
\hline 26. & Psychotria sp. & Memaren & 3 & 0,974 & 2,439 & & 3,413 \\
\hline 27. & $\begin{array}{l}\text { Ilex cymosa Blume } \\
\text { Tiang }\end{array}$ & Merpala & 2 & 0,649 & 2,439 & & 3,088 \\
\hline 28. & $\begin{array}{l}\text { Melaleuca leucadendron L } \\
\text { Pohon }\end{array}$ & Gelam & 78 & 100 & 100 & 100 & 300 \\
\hline 29. & Melaleuca leucadendron $\mathrm{L}$ & Gelam & 71 & 100 & 100 & 100 & 300 \\
\hline
\end{tabular}

Keterangan : JI: Jumlah Individu; KR: Kerapatan Relatif; FR: Frekuensi Relatif; DR: Dominasi Relatif; INP: Indeks Nilai Penting

Jumlah individu pada setiap spesies mempengaruhi tingkat keragaman suatu vegetasi. Purwaningsih \& Yusuf (2005), menyatakan bahwa tingkat keragaman vegetasi dipengaruhi oleh jumlah individu pada setiap spesies. Sedikitnya jumlah individu yang ditemukan dalam setiap spesies menyebabkan tingginya keragaman dalam suatu komunitas. Selain itu, Lisdayanti et al. (2016), menyatakan bahwa perbandingan jumlah individu yang banyak belum tentu menjamin akan berhasilnya tumbuhan mencapai tingkat pertumbuhan selanjutnya. Hal ini dapat dilihat dari jumlah individu ataupun jenis yang menurun dari tingkat pancang ke tiang dan pohon.

Berdasarkan analisis vegetasi menunjukkan spesies dari famili Myrtaceace ditemukan pada semua tingkatan yaitu $M$. leucadendron L (Tabel 2). Spesies $M$. leucadendron L memiliki nilai INP yang tinggi pada tingkat tiang (300\%), pohon $(300 \%)$, dan pancang 204
$(115,640 \%)$. Hal ini menunjukkan M. leucadendron L merupakan spesies dominan pada tingkat pertumbuhan pancang, tiang, dan pohon. $M$. leucadendron L merupakan spesies yang paling banyak tumbuh di Indonesia, terutama tumbuh di perkebunan dan hutan alam dan memiliki manfaat sebagai penghasil produksi minyak atsiri terutama pada bagian daunnya (Pujiarti et al., 2011). Spesies ini juga termasuk sebagai salah satu tanaman penghasil produk hasil hutan bukan kayu yang memiliki prospek cukup baik untuk dikembangkan dan perlu kajian pemanfaatan dan upaya konservasi sebagai suatu upaya untuk menanggulangi ancaman terhadap kelestarian keanekaragaman jenis (Indrawan et al., 2007).

Menurut Setiadi (2005), menyatakan bahwa spesies dominan ditunjukkan melalui nilai penting tertinggi, yang diindikasikan dengan nilai kerapatan relatif, frekuensi relatif dan dominasi relatif yang 
lebih tinggi dari spesies lainnya. Sementara tingkat semai, spesies yang mendominasi adalah Cyperus sp. $(58,617 \%)$ dan $M$. leucadendron L (41,028 \%). Dominannya Cyperus sp. pada tingkat semai, menandakan spesies ini mempunyai kemampuan untuk tumbuh dan adaptasi di hutan rawa air tawar.

Penelitian Abywijaya (2014), tumbuhan bawah yang memiliki INP tertinggi di jalur Waruwaru adalah spesies Cyperus sp. Hal ini terjadi karena jalur Waruwaru memiliki beberapa telaga air tawar. Selain itu, spesies-spesies dari genus Cyperus umum tumbuh ditepian badan air tawar. Penelitian Purborini (2006), Cyperus sp. cenderung ditemukan di kawasan rawa area limnetik.

\subsection{Indeks Keragaman Komunitas}

Indeks Shannon-Wienner menunjukkan tingkat keragaman tumbuhan yang rendah di hutan rawa air tawar. Hal ini terlihat dari nilai indeks keanekaragaman yang lebih kecil $(<3)$ pada setiap tingkat pertumbuhan (Tabel 3). Indeks ShannonWeiner tergantung pada jumlah individu pada spesies tumbuhan. Indeks keragaman yang sedang ditemukan pada tingkat semai dan pancang yang berkisar 1 sampai 3 yaitu 2,197 dan 1,591. Pada tingkat tiang dan pohon lebih kurang dari 1 yaitu 0 . Hal ini menunjukkan bahwa indeks keanekaragaman tingkat tiang dan pohon termasuk dalam kriteria rendah. Menurut Setiadi (2005), nilai indeks keanekaragaman dapat berkisar antara 0-7, dengan kriteria: 0-2 (rendah), 2-3 (sedang), dan > 3 (tinggi). Selain itu, menurut Lisdayanti et al. (2016), bahwa indeks keragaman menggambarkan tingkat kestabilan dalam suatu komunitas. Secara umum pada lokasi yang diamati bahwa komunitas hutan rawa air tawar di TWA Jering Menduyung dalam kondisi yang kurang stabil.

\begin{tabular}{cccccc}
\multicolumn{2}{c}{ Tabel 3. Indeks Keragaman Seluruh Tingkat Pertumbuhan di Hutan Rawa Air Tawar TWA Jering Menduyung } \\
\hline No. & Indeks keragaman (Diversity index) & $\begin{array}{c}\text { Semai } \\
\text { (Seedling) }\end{array}$ & $\begin{array}{c}\text { Pancang } \\
\text { (Saplings) }\end{array}$ & $\begin{array}{c}\text { Tiang } \\
\text { (Poles) }\end{array}$ & $\begin{array}{c}\text { Pohon } \\
\text { (Trees) }\end{array}$ \\
\hline 1. & Indeks keragaman (Shannon -Wienner index) & 2,197 & 1,591 & 0 & 0 \\
2. & Indeks kemerataan (Evennes Index) & 0,792 & 0,663 & 0 & 0 \\
\hline
\end{tabular}

Indeks kemerataan untuk semua tingkat pertumbuhan (semai, pancang, tiang dan pohon) di hutan rawa air tawar memiliki nilai kurang dari satu, yaitu berkisar antara 0-0,792 (Tabel 3). Indeks kemerataan memiliki nilai antara 0-1 dimana nilai 1 menunjukkan distribusi spesies yang sama dalam suatu komunitas (Lisdayanti et al., 2016). Menurut Gunawan et al. (2011), menyatakan nilai kemerataan suatu jenis ditentukan oleh distribusi setiap jenis pada masing-masing plot secara merata. Semakin merata suatu jenis dalam suatu ekosistem/tipe vegetasi hutan, maka semakin tinggi nilai kemerataannya. Berdasarkan kriteria tersebut, maka dapat dikatakan bahwa distribusi setiap spesies pada semua tingkat pertumbuhan di hutan rawa air tawar di TWA Jering Menduyung tidak sama. Hal ini umum terjadi dalam komunitas hutan. Menurut Indriyanto (2006), mengatakan bahwa distribusi spesies di alam cenderung mengelompok.

\subsection{Faktor Lingkungan Penting pada Setiap Tingkat Vegetasi}

Perbedaan jumlah individu maupun spesies terjadi pada setiap tingkat pertumbuhan dipengaruhi oleh faktor abiotik. Perbedaan karakteristik kawasan hutan seperti iklim, tanah, topografi, dan hidrologi yang menjadi penyebab adanya perbedaan keragaman vegetasi pada suatu kawasan hutan. Kemudian, Purwaningsih \& Yusuf (2005), menyatakan tanah memiliki pengaruh yang nyata terhadap penyediaan berbagai unsur hara. Selain itu, Lisdayanti et al. (2016), mengatakan bahwa peran sifat-sifat tanah mempunyai pengaruh penting terhadap suatu komposisi komunitas tumbuhan. Nilai rata-rata faktor fisik dan kimia tanah hutan rawa air tawar di TWA Jering Menduyung (Tabel 4).

Vegetasi pohon dalam perkembangannya memerlukan unsur hara yang cukup dan sesuai untuk kelangsungan pertumbuhannya. Adapaun unsurunsur yang perlukan tumbuhan tersebut diantaranya yaitu Nitrogen (N), Fosfor (P), dan Kalium (K) (Daty et al., 2015). Pada lokasi penelitian nilai N (0.21\%), P (2 ppm), K (45) (Tabel 4). Dari hasil tersebut untuk unsur N dalam kriteria sedang, P sangat rendah, dan $\mathrm{K}$ tinggi. Sebagaimana Barchia (2006), menyatakan bahwa kriteria sifat kimia tanah seperti unsur $\mathrm{N}$ dikatakan sedang apabila berkisar 0,21\%-0,50\%, $\mathrm{P}$ sangat rendah $<10(\mathrm{ppm})$, dan K tinggi berkisar 41-60 (mg/100g). Menurut Kunarso \& Azwar (2013), menyatakan Nitrogen (N) merupakan unsur hara esensial yang dibutuhkan dalam jumlah banyak untuk menunjang kelangsungan pertumbuhan tanaman. Kandungan $\mathrm{N}$ pada semua jenis tegakan termasuk dalam kategori sedang. Kandungan $\mathrm{N}$ di dalam tanah diduga dipengaruhi oleh tidak adanya tumbuhan dari famili Leguminosae yang secara alamiah mampu mengikat unsur $\mathrm{N}$ dari udara. Kemudian, menurut Noor (2004), ketersediaan unsur P pada tanah yang masam cenderung rendah sampai sangat rendah.

Selain itu, hasil analisis tanah menunjukkan bahwa pada hutan rawa air tawar dari beberapa kandungan Natrium ( $\mathrm{Na}=1,16 \mathrm{me} / 100 \mathrm{~g})$, Magnesium $(\mathrm{Mg}=1,35 \mathrm{me} / 100 \mathrm{~g})$ (Tabel 4). Menurut Barchia (2006), menyatakan bahwa $\mathrm{Na}$ dikatakan sangat tinggi apabila $>1,0(\mathrm{me} / 100 \mathrm{~g})$ dan $\mathrm{Mg}$ sedang apabila berkisar 1,1-2,0 (me/100 g). Magnesium (Mg) sebagai 
unsur hara sekunder diperlukan tumbuhan dalam jumlah banyak. Sebaliknya natrium (Na), kandungan natrium yang agak berlebihan diduga dapat menyebabkan sebagian dari tumbuhan tidak dapat beradaptasi dengan baik di daerah setempat (Purwaningsih \& Yusuf, 2005).

Tabel 4. Analisis Sifat Fisik Kimia Tanah Hutan Rawa Air Tawar di TWA Jering Menduyung

\begin{tabular}{|c|c|c|c|c|c|}
\hline No. & \multicolumn{2}{|l|}{ Parameter } & Metode & Satuan & Hasil \\
\hline 1. & \multicolumn{2}{|l|}{ C-Organik } & Walkely \& Black/Gravimetri & $\%$ & 6,48 \\
\hline 2. & \multicolumn{2}{|l|}{ N-Total } & Kjeldahl & $\%$ & 0,21 \\
\hline 3. & \multicolumn{2}{|l|}{ C/N Ratio } & Penghitungan & - & 31 \\
\hline 4. & \multicolumn{2}{|l|}{$\mathrm{P}_{2} \mathrm{O}_{5}$ Tersedia } & Bray/Olsen & ppm & 2 \\
\hline 5. & \multicolumn{2}{|l|}{$\mathrm{P}_{2} \mathrm{O}_{5}$ Potensial } & $\mathrm{HCl} 25 \%$ & $\mathrm{mg} / 100 \mathrm{~g}$ & 6 \\
\hline 6. & \multicolumn{2}{|l|}{$\mathrm{K}_{2} \mathrm{O}$ Potensial } & $\mathrm{HCl} 25 \%$ & $\mathrm{mg} / 100 \mathrm{~g}$ & 45 \\
\hline \multirow[t]{4}{*}{7.} & \multirow[t]{4}{*}{ Kation Dapat Ditukar } & $\mathrm{K}^{+}$ & & \multirow[t]{4}{*}{$\operatorname{cmol}(+) / \mathrm{kg}$} & 0,19 \\
\hline & & $\mathrm{Na}^{+}$ & & & 1,16 \\
\hline & & $\mathrm{Ca}^{++}$ & $\mathrm{N} \mathrm{NH}_{4} \mathrm{OAC}$ & & 1,29 \\
\hline & & $\mathrm{Mg}^{++}$ & & & 1,35 \\
\hline \multirow[t]{2}{*}{8.} & \multirow[t]{2}{*}{ Kemasaman Dapat Tukar } & Al-dd & $N \in C l$ & \multirow[t]{2}{*}{$\operatorname{cmol}(+) / \mathrm{kg}$} & 1,95 \\
\hline & & H-dd & $N \mathrm{KCl}$ & & 0,76 \\
\hline 9. & Kapasitas Tukar Kation & & $N \mathrm{NH}_{4} \mathrm{OAC}$ & $\mathrm{Cmol}(+) / \mathrm{kg}$ & 12,50 \\
\hline 10. & Kejenuhan Basa & & Penghitungan & $\%$ & 31,85 \\
\hline 11. & Kadar Air & & Gravimetri & $\%$ & 2,3 \\
\hline \multirow[t]{2}{*}{12.} & \multirow[t]{2}{*}{$\mathrm{pH}$} & $\mathrm{H}_{2} \mathrm{O}$ & \multirow{3}{*}{ Potensiometri } & \multirow{3}{*}{ - } & 4,5 \\
\hline & & $\mathrm{KCl} 1 \mathrm{~N}$ & & & 3,5 \\
\hline \multirow[t]{3}{*}{13.} & \multirow[t]{3}{*}{ Tekstur 3 Fraksi } & Pasir & & & $-{ }^{*}$ \\
\hline & & Debu & Pipet & $\%$ & $--^{*}$ \\
\hline & & Klei & & & $-^{*}$ \\
\hline 14. & Bulk density & & & $\mathrm{g} / \mathrm{cm}^{3}$ & 0,54 \\
\hline 15. & Porositas & & & $\%$ & 79,48 \\
\hline
\end{tabular}

Keterangan: *)Tekstur 3 fraksi tidak dilakukan analisis jika kadar C Organik > 5\%

Tingkat kemasaman tanah pada lokasi penelitian yaitu 4,5 seperti yang tersaji pada Tabel 4 diatas, dimana $\mathrm{pH}$ ini tergolong sangat masam. Ardhana (2012), menyatkan bahwa $\mathrm{pH}$ tanah dikatakan sangat masam apabila berada $<4,5$, kemudian di daerah rawa tanah sangat masam disebabkan banyak mengandung asam sulfat. Menurut Barchia (2006), kemasaman tanah yang tinggi akan mendestruksi mineral-mineral liat tanah sehingga kation-kation akan terlarut. Kation-kation seperti $\mathrm{Ca}, \mathrm{Mg}, \mathrm{K}$ dan $\mathrm{Na}$ akan tercuci, sementara kation-kation $\mathrm{Al}, \mathrm{Fe}, \mathrm{Mn}$ akan mendominasi larutan tanah dan tapak pertukaran kation pada koloid tanah. Sangat masamnya tanah di lokasi penelitian mempengaruhi penyediaan unsur makro dan mikro bagi sistem perakaran vegetasi yang tumbuh di atasnya. Ardhana (2012), menyatakan bahwa umumnya, unsur hara diserap oleh tanaman pada $\mathrm{pH}$ tanah netral 6-7, karena pada $\mathrm{pH}$ tersebut sebagian besar unsur hara mudah larut di dalam air.
Selain itu, pada tanah yang masam banyak ditemukan unsur Al yang selain bersifat racun juga mengikat Phospor, sehingga tidak dapat diserap oleh tanaman.

Kemudian, spesies yang dominan di hutan rawa yaitu $M$. leucadendron L, memiliki kemampuan untuk tumbuh dilahan rawa yang masam dan tergenang. Menurut Pramono et al. (2016), M. leucadendron L termasuk dalam famili Myrtaceae merupakan tumbuhan perdu atau pohon yang tumbuh di daerah rawa atau hutan sekunder yang berbatasan dengan rawa. $M$. leucadendron $\mathrm{L}$ tumbuh pesat pada lahan terlantar yang masam dan tergenang. Selain itu, pada $\mathrm{pH}$ tanah dapat mencapai $\mathrm{pH}<2,5$, kondisi kemasaman ini tidak adalagi tanaman budidaya yang mampu tumbuh, sehingga tanah sulfat masam demikian biasanya akan menjadi lahan terlantar dan akan ditumbuhi oleh tumbuhan pioner seperti kayu $M$. leucadendron L dan akhirnya membentuk hutan sekunder (Noor, 2004).

Tabel 5. Hasil Pengukuran Mikroklimat Hutan Rawa Air Tawar di TWA Jering Menduyung, Bangka Barat

\begin{tabular}{llcc}
\hline No. & Parameter & Satuan & Hasil \\
\hline 1. & Suhu Tanah & oC & $26,5-27$ \\
2. & Suhu Udara & oC & $30,8-30,9$ \\
3. & Kelembapan Udara & $\%$ & $64-73$ \\
4. & Intensitas Cahaya & Klx & $5,20-6,00$ \\
\hline \multicolumn{2}{l}{ Sumber data diolah dari hasil Pengukuran Mikroklimat } & &
\end{tabular}

Faktor pembatas pertumbuhan selain ketersediaan unsur hara, yaitu intensitas cahaya, suhu udara, suhu tanah, kelembapan udara, dan ketersediaan air. Beberapa faktor lingkungan di hutan rawa air tawar TWA Jering Menduyung yaitu Suhu udara $30,8-30,9^{\circ} \mathrm{C}$, suhu tanah $26,5-27^{\circ} \mathrm{C}$, dan kelembapan udara $64 \%-73 \%$ (Tabel 5). Suhu udara di hutan rawa tergolong cukup tinggi, tetapi untuk kelembapan udara tidak dikategorikan ideal. Menurut Noor (2004), suhu udara kawasan rawa cukup tinggi, tetapi kelembapan tinggi. Suhu rata-rata berkisar antara $26-34^{\circ} \mathrm{C}$ dan kelembapan lebih tinggi dari $80 \%$. Suhu dan kelembapan ini dipengaruhi oleh jenis dan kerapatan vegetasi yang menutupi. Intensitas cahaya di hutan rawa air tawar cukup tinggi berkisar 5,206,00 Klx (Tabel 5). Selain cahaya, faktor pembatas 
lainnya adalah air. Menurut Lisdayanti et al. (2016), mengatakan bahwa faktor pembatas pada pola eksponensial antara lain pada saat musim penghujan tiba, maka ruang tumbuh akan tergenang air, sehingga membatasi semai tumbuh menjadi pancang, namun menjadi kering pada musim kemarau, sehingga memungkinkan keberhasilan pertumbuhan pada tingkat pancang.

\section{Kesimpulan}

Penelitian yang dilakukan pada hutan rawa air tawar TWA Jering Menduyung tercatat jumlah jenis tumbuhan sebanyak 25 jenis dari 19 famili. Selain itu, terdapat 3 famili yang memiliki jumlah spesies lebih banyak dibandingkan familli lainnya, yaitu Rubiaceae, Myrtaceae, dan Pteridaceae. Untuk indeks nilai penting (INP), M. leucadendron L merupakan spesies yang mendominasi pada tingkat pertumbuhan pancang, tiang dan pohon. Sementara tingkat semai, spesies yang mendominasi adalah Cyperus sp. $(58,617$ \%) dan M. leucadendron L (41,028 \%). Kemudian, indeks keragaman di hutan rawa air tawar terbilang rendah. Indeks keragaman yang sedang ditemukan pada tingkat semai dan pancang yang berkisar 1 sampai 3 yaitu 2,197 dan 1,591. Indeks kemerataan untuk semua tingkat pertumbuhan (semai, pancang, tiang dan pohon) di hutan rawa air tawar memiliki nilai kurang dari satu, yaitu berkisar antara 0-0,663, dimana menunjukkan distribusi spesies yang tidak sama.

\section{DAFTAR PUSTAKA}

Abotsi, K.E., Radji, A.R., Rouhan, G., Dubuisson, J.Y., \& Kokou, K. (2015). The Pteridaceae family diversity in Togo. Biodiversity Data Journal. 3(1): 1-63.

Abywijaya, I. (2014). Keanekaragaman dan Pola Sebaran Spesies Tumbuhan Asing Invasif di Cagar Alam Pulau Sempu, Jawa Timur. Jurnal Biologi Indonesia. 10(2): 221-235.

Ardhana, I.P. (2012). Ekologi Tumbuhan. Denpasar: Universitas Udayana.

Barchia, M. (2006). Gambut Agroekosistem dan Transformasi Karbon. Yogyakarta: Gadjah Mada University Press.

BKSDA SUMSEL [Balai Konservasi Sumber Daya Alam Sumatera Selatan]. (2017). Profil Jering Menduyung. Bangka Belitung.

Borges, J.G., Marques, S., Garcia-Gonzalo, J., Rahman, A.U., Bushenkov, V., Sottomayor, M., Nordström, E.M. (2017). A Multiple Criteria Approach for Negotiating Ecosystem Services Supply Targets and Forest Owners' Programs. Forest Science. 63(1): 49-61.

Daty, N.I., Hardiansyah, \& Amintarti, S. (2015). Komposisi dan Struktur Vegetasi Pohon di Kawasan Pulau Telo Kecamatan Selat Kabupaten Kapuas. Jurnal WahanaBio. 13(1): 71-92.

Delprete, P.G., \& Jardim, J.G. (2012). Systematics, taxonomy and floristics of Brazilian Rubiaceae: An overview about the current status and future challenges.
Rodriguesia. 63(1): 101-128.

Govaerts, R., Frodin, D.G., Ruhsam, M., Bridson, D.M., \& Davis, A.P. (2007). World checklist \& bibliography of Rubiaceae. Kew: The Trustees of the Royal Botanic Gardens.

Gunawan, W., Basuni, S., Indrawan, A., Prasetyo, L.B., \& Soedjito, H. (2011). Analisis Komposisi dan Struktur Vegetasi Terhadap Upaya Restorasi Kawasan Hutan Taman Nasional Gunung Gede Pangrango. JPSL. 1(2): 93-105.

Indrawan, M., Primack, R.B., \& Supriatna, J. (2007). Biologi Konservasi. Jakarta: Yayasan Obor Indonesia.

Indriyanto. (2006). Ekologi Hutan. Jakarta: Penerbit Bumi Aksara.

Kunarso, A., \& Azwar, F. (2013). Keragaman Jenis Tumbuhan Bawah pada Berbagai Tegakan Hutan Tanaman di Benakat, Sumatera Selatan. Jurnal Penelitian Hutan Tanaman. 10(2): 85-98.

Lafare, B., Pitopang, R., \& Suleman, S.M. (2018). Komposisi Jenis Tumbuhan herba pada Hutan Pegunungan di sekitar Danau Kalimpa'a Kawasan taman Nasional Lore Lindu Sulawesi Tengah. Biocelebes. 12(3): 5464.

Lisdayanti, L., Hikmat, A., \& Istomo, I. (2016). Komposisi Flora dan Keragaman Tumbuhan di Hutan Rawa Musiman, Rimbo Tujuh Danau Riau. Jurnal Penelitian Hutan dan Konservasi Alam. 13(1): 15-28.

Martins, H., \& Borges, J.G. (2007). Addressing collaborative planning methods and tools in forest management. Forest Ecology and Management. 248(1-2): 107-118.

Melawati, J., Susiati, H., \& Wahyuningsih, F. (2011). Kajian Awal Keberadaan Flora dan Fauna Langka pada Kegiatan Pra-survei Tapak PLTN di Pulau Bangka. In Prosiding Seminar Nasional Pengembangan Energi Nuklir (pp. 135-144). Jakarta: Badan Tenaga Nuklir Nasional.

Noor, M. (2004). Lahan Rawa: Sifat dan Pengelolaan Tanah Bermasalah Sulfat Masam. Jakarta: PT Raja Grafindo Persada.

Pramono, A.A., Syamsuwida, D., \& Aminah, A. (2016). Variasi produksi benih gelam (Melaleuca leucadendron) pada beberapa tegakan di Sumatera Selatan. Pros Sem Nas Masy Biodiv Indon. 2(2): 143-148.

Pujiarti, R., Ohtani, Y., \& Ichiura, H. (2011). Physicochemical properties and chemical compositions of Melaleuca leucadendron leaf oils taken from the plantations in Java, Indonesia. Journal of Wood Science. 57(5): 446451.

Purborini, D. (2006). Struktur dan Komposisi Tumbuhan di Kawasan Rawa Pening Kabupaten Semarang Jawa Tengah. Universitas Negeri Semarang.

Purwaningsih. (2009). Analisa Vegetasi Hutan Riparian Dataran Rendah di Tepi Sungai Nggeng, Taman Nasional Kayan Mentarang, Kalimantan Timur. Berita Biologi. 9(5): 547-559.

Purwaningsih, \& Yusuf, R. (2005). Species composition and vegetation structure in Pakuli area, Lore Lindu National Park, Central Sulawesi. Biodiversitas, Journal of Biological Diversity. 6(2): 123-128.

Schall, P., \& Ammer, C. (2013). How to quantify forest management intensity in Central European forests. European Journal of Forest Research. 132(2): 379396.

Sedio, B.E., Wright, S.J., \& Dick, C.W. (2012). Trait evolution 
and the coexistence of a species swarm in the tropical forest understorey. Journal of Ecology. 100(5): 11831193.

Setiadi, D. (2005). Keanekaragaman Spesies Tingkat Pohon di Taman Wisata Alam Ruteng, Nusa Tenggara Timur. Biodiversitas. 6(1): 118-122.

Sharma, N., \& Joshi, S. (2008). Comparative Study of a Fresh Water Swamp of Doon Valley. The Journal of
American Science. 4(1): 7-10.

Tuheteru, F.D., \& Mahfudz. (2012). Ekologi, Manfaat dan Rehabilitasi, Hutan Pantai Indonesia. Manado: Balai Penelitian Kehutanan Manado.

Yusuf, R., \& Purwaningsih. (2009). Studi Vegetasi Hutan Rawa Air Tawar di Cagar Alam Rimbo Panti, Sumatera Barat. Berita Biologi. 9(5): 491-508. 